\title{
Ultrasound Assisted Extraction of Micro and Macroelements in Fruit Peels Powder Mineral Supplement for Osteoporosis Patients and their Determination by Flame Atomic Absorption Spectrometry
}

\section{Muhammad Saleem}

University of Engineering and Technology

Arjumand Iqbal Durani

University of Engineering and Technology

Rima D. Alharthy

King Abdulaziz University

Mahmood Ahmed (D mahmoodresearchscholar@gmail.com )

Renacon Pharma Limited

Muhammad Imtiaz Shafiq

School of Biochemistry and Biotechnology, Lahore 54590, Pakistan

Abdul Hameed

University of Sahiwal

Syed Mubasher Hussain

University of Engineering and Technology

Waqas Bashir

University of Engineering and Technology

\section{Research Article}

Keywords: Bone health, Osteoblasts, Osteoclasts, Ultrasound Extraction, Spectrometry

Posted Date: August 4th, 2021

DOl: https://doi.org/10.21203/rs.3.rs-733194/v1

License: (c) (i) This work is licensed under a Creative Commons Attribution 4.0 International License.

Read Full License 
Version of Record: A version of this preprint was published at Journal of Chemistry on December 24th, 2021. See the published version at https://doi.org/10.1155/2021/5151560. 


\section{Abstract}

Osteoporosis is a worldwide disease depicted by the reduced bone mass, an adequate supply of minerals are needed to support bone remodelingand their deficiency causes bone-related diseases, osteoporosis in particular, and have osteo-protective effects. The aim of recent researchwas to quantify the micro ( $\mathrm{Mn}, \mathrm{Fe}$, $\mathrm{Cu}$, and $\mathrm{Zn})$ and macroelements $(\mathrm{Mg}, \mathrm{K}$, and $\mathrm{Ca})$ in the peels powder of some common fruits (pomegranate, orange, lemon, mango, and grapefruit) by flame atomic absorption spectrometer (FAAS). The extraction of micro and macroelements in peels powder was done by using dilute acids in ultrasonic bath. Apple leaves were used as standard reference material (SRM, NIST 1515) to optimize the ultrasound assisted extraction (UAE) method at varied operating parameters. Maximum response was obtained for extracting of minerals in $500 \mathrm{mg}$ SRM at $60^{\circ} \mathrm{C}$ temperature, setting a vortexing time of 5 min.while using $5.0 \mathrm{~mL}$ extracting agent $\mathrm{HNO}_{3}(0.5 \mathrm{M})-\mathrm{H}_{2} \mathrm{O}_{2}(10 \%)$ at90\% sonication amplitude of ultrasound bath for $6 \mathrm{~min}$. While analyzing the SRM, the percentage recovery wasobtained in ranged between $96.8-102.7 \%$ to assure the accuracy whereasrepeatability $(n=10)$ study in terms of $\%$ RSDyielding $\leq 2.29$ well support the precision of proposed method and limits of quantitation $(\mu \mathrm{g} / \mathrm{g}$ ) were $0.034,0.061,0.065,0.057,0.017,0.175$ and 0.053 for $\mathrm{Mn}, \mathrm{Fe}, \mathrm{Cu}, \mathrm{Zn}, \mathrm{Mg}, \mathrm{K}$ and Ca respectively. The proposed UAE method was reliable,efficient, and advantageous over the conventionally employed acid digestion method with regards to less consumption of reagents and short analysis time for the determination of micro and macroelements in fruit peels powder.

\section{Introduction}

Osteoporosis is a worldwide disease depicted by the reduced bone mass followed by the microarchitectural decay of bone tissues which results in the elevated risk of bone fracture. Annually more than $\mathbf{2 0 0}$ million cases of osteoporosis are reported as active case worldwide, with approximately 2 million case are of hip fractures ${ }^{1,2}$. Younger women with estrogen deficiency while older ones undergone the menopause are primarily caught by osteoporosis whereas secondary osteoporosis occurs even occurs in younger individuals (both male and female) by chronic use of steroids like corticosteroids ${ }^{3}$. Its prevalence in Pakistan is also high, according to an estimation 5.6-17.8 \% pre-menopausal women and $20-49.3 \%$ post-menopausal women become a victim of it ${ }^{4}$. To prevent the osteoporosis, maintenance and development of bone mass, nutrition particularly mineralization play an important role. Osteoclasts are specialized, multinucleated cells which are involved in bone development and regeneration, also ensure the bone mineralization. So an adequate supply of minerals (macroelements: $\mathrm{Mg}, \mathrm{K}, \mathrm{Ca}$ and microelements: $\mathrm{Mn}, \mathrm{Fe}, \mathrm{Cu}, \mathrm{Zn}$ ) and vitamins are needed to support bone remodeling 2,5 . The importance of these minerals other than Ca for good bone health can hardly be overemphasized. Several studies have been conducted to link these minerals with bone health and their deficiency causes bone-related diseases, osteoporosis in particular, and have osteo-protective effects ${ }^{5-7}$.

Most of the Ca (about $99 \%$ ) found in body is associated with bones that plays a major role in bone strength and health throughout life and bone loss associated with aging is managed by adequate $\mathrm{Ca}$ 
intake. Marginal $\mathrm{Ca}$ intake or its deficiency is an important factor underlying osteoporosis and increased bone fracture risk ${ }^{3,8}$. Hydroxyapatite production is supported by $\mathrm{Mg}^{9}$, about $60 \%$ of its total in the body is stored in the skeleton and this constitutes about $1 \%$ of the total bone mineral content. Mg deficiency via hypocalcemia elevates osteoclast activity while the osteoblastic number and activity decline, so it has a major role in Ca metabolism ${ }^{10,11}$. Ca hemostasis influenced by potassium particularly excretion and conservation of urinary $\mathrm{Ca}$ and bone density is closely related to $\mathrm{K}$ intake and its higher intake associated with less bone loss ${ }^{12}$. Mn is a constituent of some enzymes and is distributed in tissues throughout including bone. It plays an important role in bone formation, the thickness of the trabecular bone area, and its mineralization. Utilization of $\mathrm{Mn}$ in combination with $\mathrm{Cu}, \mathrm{Zn}$, and $\mathrm{Ca}$ is more effective in preventing spinal bone loss than alone using $\mathrm{Ca}^{2,13}$. Fe has a bone protective effect, it plays an enzymatic co-factor to stimulate the synthesis of bone matrix and mineralization via activation of lysyl hydroxylase and 25-hydroxycholecalciferol respectively ${ }^{14,15}$. Skeletal abnormalities associated with $\mathrm{Cu}$ deficiency, in osteoporosis malabsorption of $\mathrm{Cu}$ has also its role. Cu removes bone-free radicals that cause osteoclast activation and also inhibit osteoclastic bone resorption directly 2,16 . A large portion of the total body burden of $\mathrm{Zn}$ exists in skeletal and $\mathrm{Zn}$ related proteins regulate cellular function in osteoblasts and osteoclasts. Zn increases osteoblastic activity and inhibits osteoclastic bone resorption 17,18 .

Fruits are consumed across the world as a rich source of nutrients like minerals, vitamins, fiber, and other bioactive compounds that are required for a healthy human life. As a result of increased consumption of the fruits that leads to the wastage of the fruits especially their peels and seed. But the recent studies show that the peels and seeds are a rich source of various valuable chemicals as compare to pulp ${ }^{19}$. So the peels of these fruits should be focused on their use in the manufacturing of various cereals used as breakfast, dietary supplements, and in the formulation of a nutraceutical for the treatment of bone-related problems especially in aged women ${ }^{20}$. Nutritive values of edible parts of the fruits are focused more and the peels are usually considered as agro wastes but the study has revealed that some minerals are even more concentrated in fruit peels than in the edible parts of the fruits ${ }^{21}$. Hundreds of tons of fruit peels are produced each year and the wastage of peel means the wastage of minerals.

Mixture of concentrated acids alone or in combination with hydrogen peroxide are widely used as extracting agents for the extraction of metals in different food matrices by employing microwaveassisted digestion or conventional acid digestion methods. High pressure and temperature along with large volume of reagents (acids and hydrogen peroxide) are required for getting adequate results by using the these digestion methods ${ }^{22-24}$. Ultrasound-assisted extraction (UAE) is promisingly alternative method to microwave-assisted digestion or conventional acid digestion methods to get adequate results and enough potential for extracting of metals in different food matrices, sediments ${ }^{25}$, animal and plant tissues ${ }^{26,27}$ where ultrasonic energy is used to make easier the process of extraction in the presence of matrix analyte. 
Also keeping in view the principles of green chemistry, UAE method in combination with dilute acids to extract the metals is generating less waste which is harmful to environment, also this method has advantages over the conventional digestion/extractions methods related to operating costs, safety, simplicity, and reduced extraction time ${ }^{28,29}$. The main target of the current research is to investigate the micro ( $\mathrm{Mn}, \mathrm{Fe}, \mathrm{Cu}$, and $\mathrm{Zn}$ ) and macroelements ( $\mathrm{Mg}, \mathrm{K}$, and $\mathrm{Ca}$ ) composition in the peel's powder of some common fruits (pomegranate, orange, lemon, mango, and grapefruit). UAE method was optimized prior to determination of their concentration by flame atomic absorption spectrometer (FAAS). Consequently suggest these fruit peels powder a non-chemical/organic source of micro and macroelements having nutritional benefits for the patients of osteoporosis in terms to overcome skeletal abnormalities and improve bone health.

\section{Materials And Methods \\ 2.1. Reagents and solutions}

Hydrochloric acid $(37 \% \mathrm{~m} / \mathrm{m})$, Nitric acid, $(65 \% \mathrm{~m} / \mathrm{m})$, and hydrogen peroxide (30 \% v/v) of reagent grade (Sigma Aldrich, USA) for digestion of fruit peels powder samples and preparation of extracting agents were purchased from Falcon Chemicals, Lahore-Pakistan. Standard solutions of each metal to construct respective calibration curve were prepared by diluting the certified reference standard, 1000 $\mathrm{mg} / \mathrm{L}$ of each metals (Merck, Germany) with $\mathrm{HNO}_{3}(2 \% \mathrm{v} / \mathrm{v})$ whereas glassware employed in this procedure was soaked in $\mathrm{HNO}_{3}(20 \% \mathrm{v} / \mathrm{v})$ to avoid any contamination. $18 \mathrm{M} \Omega . c m$ resistivity quality water was prepared in our own lab by GenPure water system (Thermo Scientific, USA) for diluting the solutions. Apple leaves were used as standard reference standard (NIST 1515) for FAAS method validation.

\subsection{Collection of samples}

Fresh fruits samples including pomegranate, orange, lemon, mango, and grapefruit were collected from one supplier located in the provincial capital of Punjab province of Pakistan viz. Lahore. Three packets were collected randomly, from each pack of fruit sample, three samples were collected for each fruit, and in total, 45 fruit samples ( 3 packets $\times 3$ fruits $\times 5$ fruit species) were used in this study. The plant material was authenticated by plant taxonomist from Institute of Agriculture Sciences, University of the Punjab, Lahore-Pakistan. A voucher specimen (DCUET-020219) was deposited at the Institute's herbarium. After collection, the fruit samples were washed with ultrapure water, then peeled off. The fruit peels were dried for $72 \mathrm{~h}$ at $60^{\circ} \mathrm{C}$ after washing with ultrapure water, the dried peels were grinded by using knife mill and screened through 100 US mesh then packed in airtight glass jar and stored at $4^{\circ} \mathrm{C}$ till further analysis. The plant used in this research comply the criteria and policy established by "Convention on the Trade in Endangered Species of Wild Fauna and Flora and the IUCN Policy Statement on Research Involving Species at Risk of Extinction"

\subsection{Extraction and digestion of samples}




\subsubsection{Ultrasound-assisted extraction}

Apple leaves as SRM were used to optimize the UAE method for extraction of micro and macroelements, and extraction was performed by using $\mathrm{HNO}_{3}$ [EA-1], $\mathrm{HNO}_{3}-\mathrm{HCl}(1: 3)$ [EA-2] and $\mathrm{HNO}_{3}-\mathrm{H}_{2} \mathrm{O}_{2}$ (2:1) [EA-3] as extracting agents. Pre-sonication of sample was done by using pulse type vortex mixer (Digital Vortex Mixer, Thermo Scientific ${ }^{T M}$, UK) for 5-15 min. whereas sonication time (90\% sonication amplitude) and temperature of ultrasonic bath was varied from $2-20 \mathrm{~min}$. and $30-90^{\circ} \mathrm{C}$ respectively. $5.0 \mathrm{~mL}$ of extracting agent and $500 \mathrm{mg}$ finely grinded SRM was transferred to round bottom flask, and vortex for 5 , 10 , and $15 \mathrm{~min}$. then it was placed in an ultrasonic bath at 30,60 , and $90^{\circ} \mathrm{C}$ temperature for different intervals $\left(2,4,6,8,10,12,14,16,18\right.$, and 20 min.). The resulting suspension was centrifuged (Sorvall ${ }^{\text {TM }} \mathrm{ST}$ 8 , Thermo Scientific $\left.{ }^{\mathrm{TM}}, \mathrm{UK}\right)$ at $3000 \mathrm{rpm}$ for $3 \mathrm{~min}$. then supernatant was diluted with ultra-pure water and made up to volume in $25 \mathrm{~mL}$ of volumetric flask. The final solution was stored at $4^{\circ} \mathrm{C}$ till any further analysis. The optimized UAE method was applied for the determination of micro and macroelements in the fruits peels powder under investigation.

\subsubsection{Conventional acid digestion}

The finely grinded powder of fruit peels was transferred to glass digester containing concentrated $\mathrm{HNO}_{3}$ $(15 \mathrm{~mL})$, initially heated the sample at $100^{\circ} \mathrm{C}$ for $15 \mathrm{~min}$. then before adding the $\mathrm{H}_{2} \mathrm{O}_{2}(2 \mathrm{~mL})$ it was kept at $120^{\circ} \mathrm{C}$ for $2 \mathrm{~h}$ and after the addition of $\mathrm{H}_{2} \mathrm{O}_{2}$, further heated for 20 min. at the same temperature. This conventional acid digestion method also applied to SRM for the comparison of UAE with it.

The results were presented in $\mathrm{mg} 100 \mathrm{~g}^{-1}$ of dry powder mass while the analysis were carried out in triplicate whereas stock solutions of real samples and SRM were further diluted as per requirement of analysis.

\subsection{Instrumentation}

Air circulation oven (Bio-Science, China) and knife mill (GRINDOMIX GM 300, Thomas Scientific, USA) were used for drying and grinding of fruit peels respectively. Ultrasonic bath (Model 1800, Thomas Scientific, USA) and glass digester (Hach DRB 200 Dry Thermostat Reactor, Thomas Scientific, USA) were employed for UAE and CAD respectively. The composition of $\mathrm{Mn}, \mathrm{Fe}, \mathrm{Cu}, \mathrm{Zn}, \mathrm{Mg}, \mathrm{K}$, and Ca present in SRM and fruit peels powder were determined by using FAAS equipped with an auto-sampler (Model: PG-990, PG-instruments, UK). AA Win Lab® software was used to interpret the data whereas experimental design and data for optimization of AAS are explained in (Table 2) ${ }^{30,31}$. Operational parameters of AAS in present study are presented in Table 1. 
Table 1

FAAS operational parameters

\begin{tabular}{|c|c|c|c|c|c|c|c|}
\hline \multirow[t]{2}{*}{ Parameters } & \multicolumn{7}{|c|}{ Element } \\
\hline & Mn & $\mathrm{Fe}$ & $\mathrm{Cu}$ & $\mathrm{Zn}$ & $\mathbf{M g}$ & $\mathrm{K}$ & $\mathrm{Ca}$ \\
\hline Wavelength (nm) & 279.5 & 248.3 & 324.7 & 213.9 & 285.2 & 766.5 & 422.7 \\
\hline Slit width (nm) & 0.4 & 0.2 & 0.4 & 0.4 & 0.4 & 0.4 & 0.4 \\
\hline Lamp current (mA) & 5.0 & 5.0 & 5.0 & 5.0 & 5.0 & 5.0 & 5.0 \\
\hline Sample flow (mL min.-1) & 6.0 & 6.0 & 6.0 & 6.0 & 6.0 & 6.0 & 6.0 \\
\hline a Gas flow (mL min. ${ }^{-1}$ ) & 1700 & 1700 & 1700 & 1700 & 1700 & 1700 & 1700 \\
\hline Air pressure (psi) & 40 & 40 & 40 & 40 & 40 & 40 & 40 \\
\hline
\end{tabular}

Wavelength accuracy and its reproducibility were checked to optimize the AAS by using hallow cathode lamp of mercury $(\mathrm{HCL}, \mathrm{Hg}$ ) while searching the peaks at 253.7, 546.1, and $871.6 \mathrm{~nm}$ whereas bandwidth was fixed at $0.2 \mathrm{~nm}$. The wavelength accuracy was measured by difference between standard value and calculated value. For resolution studies of peaks obtained for particular element, the minima and maxima was calculated by using manganese $(\mathrm{Mn}) \mathrm{HCL}$, details parameters are provided in Table 2.

Table 2

FAAS optimization

\begin{tabular}{|lll|}
\hline Parameters & Wavelength accuracy and reproducibility & Resolution \\
\hline HCL & Mercury & Manganese \\
\hline Lamp current $(\mathrm{mA})$ & 3.0 & 2.0 \\
\hline Bandwidth $(\mathrm{nm})$ & 0.2 & 0.2 \\
\hline Negative voltage $(\mathrm{V})$ & 300 & 300 \\
\hline Gas flow (acetylene) $\left(\mathrm{mL} \mathrm{min.}^{-1}\right)$ & 1200 & 1700 \\
\hline Flame height (mm) & 5.0 & 5.0 \\
\hline Flame position (mm) & 0.0 & 0.0 \\
\hline
\end{tabular}

\subsection{Validation of proposed method}

For the validation study of proposed UAE method, percentage recovery was calculated to assess the accuracy of method after analyzing the SRM whereas paired t-test at $95 \%$ confidence of interval was performed to check the efficiency of UAE as compared to CAD. Precision was evaluated by the repetition of extraction procedure in replicates of ten $(n=10)$ under the same conditions and results of repeatability 
are expressed are in \% RSD (100 $\times \sigma / \mu$, where $\sigma$ is SD and $\mu$ is mean value). Limit of detection (LOD $=3$ $\sigma / \mathrm{S}$ ) and limit of quantitation (LOQ $=10 \sigma / \mathrm{S}$ ) were also estimated where standard deviation (SD) of analytical blank measurement $(n=18)$ was presented by $\sigma$ while $S$ is the slope of the calibration curve $(y$ $=m x+b)^{32,33}$.

\section{Results And Discussion 3.1. Optimization of AAS}

The peaks were scanned in triplicate at three different wavelengths $(253.7,546.1$, and $871.6 \mathrm{~nm})$ by using $\mathrm{HCL}$ of $\mathrm{Hg}$ the results of obtained wavelength are presented in Table 3, the difference between set and obtained wavelength represents the wavelength accuracy whereas maximum/minimum values were reported at the interval of $6 \mathrm{~h}$ to check the wavelength reproducibility which are in compliance with user requirement limit of $\pm 0.25 \mathrm{~nm}$ and $\pm 0.10 \mathrm{~nm}$ respectively.

Table 3

Wavelength accuracy and reproducibility

\begin{tabular}{|llllll|}
\hline $\begin{array}{l}\text { Set } \\
\text { wavelength } \\
(\mathrm{nm})\end{array}$ & $\begin{array}{l}\text { Obtained } \\
\text { wavelength }(\mathbf{n}=3)\end{array}$ & $\begin{array}{l}\text { Wavelength } \\
\text { accuracy }\end{array}$ & $\begin{array}{l}\text { Maximum } \\
(\mathrm{nm})\end{array}$ & $\begin{array}{l}\text { Minimum } \\
(\mathrm{nm})\end{array}$ & $\begin{array}{l}\text { Wavelength } \\
\text { reproducibility }\end{array}$ \\
\hline 253.700 & 253.685 & -0.015 & 253.715 & 253.675 & 0.040 \\
\hline 546.100 & 546.015 & -0.085 & 546.125 & 546.090 & 0.035 \\
\hline 871.600 & 871.625 & +0.025 & 871.650 & 871.585 & 0.065 \\
\hline
\end{tabular}

$\mathrm{HCL}$ of $\mathrm{Mn}$ was used to check the resolution of peaks after scanning at $279.5 \mathrm{~nm}$ in triplicate, the peaks were obtained in ranged between 279.45 and $279.71 \mathrm{~nm}$. The ratio of the maxima and minima values at first two peaks is $0.191(n=3)$ which is less than 0.30 as recommended by manufacturer. The resolution data is summarized in Table 4.

Table 4

Resolution studies

\begin{tabular}{|lll|}
\hline $\begin{array}{l}\text { Set wavelength for peak searching } \\
(\mathrm{nm})\end{array}$ & $\begin{array}{l}\text { Obtained peaks after searching } \\
(\mathrm{nm})\end{array}$ & $\begin{array}{l}\text { Maxima/minima } \\
\text { ratio }\end{array}$ \\
\hline 279.5 & $279.60,279.48,279.45$ & $14.8 / 78.1=0.189$ \\
\hline 279.5 & $279.64,279.59,279.71$ & $15.0 / 78.0=0.192$ \\
\hline 279.5 & $279.59,279.71,279.68$ & $14.9 / 78.1=0.191$ \\
\hline Average & & 0.191 \\
\hline
\end{tabular}

\subsection{Optimization of UAE}


SRM (NIST 1515) was used to optimize ( $n=6$, see supplementary data, Table 1S-8S) the UAE method by using three different extracting agents whereas operating parameters including pre-sonication, sonication and temperature were also varied (Table 5). The proposed UAE method was evaluated on the basis of the recovery studies of seven elements present in the SRM (microelements: $\mathrm{Mn}, \mathrm{Fe}, \mathrm{Cu}$, and $\mathrm{Zn}$ and macroelements: $\mathrm{Mg}, \mathrm{K}$, and $\mathrm{Ca}$ ) and compare with certified value.

Table 5

Optimized conditions for extraction of micro and elements in fruit peels powder by UAE method

\begin{tabular}{|lll|}
\hline Variables & Values & Optimized obtained value \\
\hline Pre-sonication time (min.) & $5-15$ & 5 \\
\hline Sonication time (min.) & $2-20$ & 6 \\
\hline Temperature $\left({ }^{\circ} \mathrm{C}\right)$ & $30-90$ & 60 \\
\hline Extracting agents & & \\
\hline $\mathrm{HNO}_{3}(0.5 \mathrm{M}), \mathrm{HNO}_{3}(0.5 \mathrm{M})-\mathrm{HCl}(1.0 \mathrm{M})[1: 3]$ and $\mathrm{HNO}_{3}(0.5 \mathrm{M})-\mathrm{H}_{2} \mathrm{O}_{2}$ & $\mathrm{HNO}_{3}(0.5 \mathrm{M})-\mathrm{H}_{2} \mathrm{O}_{2}(10 \%)$ \\
$(10 \%)[2: 1]$ & {$[2: 1]$} \\
\hline
\end{tabular}

The results of $\mathrm{Mn}, \mathrm{Fe}, \mathrm{Cu}, \mathrm{Zn}, \mathrm{Mg}, \mathrm{K}$, and Ca present in SRM obtained by UAE were compared with CAD method, and significance difference at $95 \%$ confidence of interval $(p=0.05)$ was assessed by comparing the $t_{\text {critical }}$ (cut off point on the $t$ distribution) and $t_{\text {experimental }}$ (experimentally compare the means of two groups) for both the methods (CAD and UAE). The value of $t_{\text {critical }}(2.57)$ was more than $t_{\text {experimental }}$ at five degrees of freedom $(n-1=5)$ which indicates no significant difference in obtained values of $\mathrm{Mn}, \mathrm{Fe}, \mathrm{Cu}$, $\mathrm{Zn}, \mathrm{Mg}, \mathrm{K}$, and Ca present in SRM by using both the methods as shown in Table 6.

Table 6. Extraction and digestion method validation by using SRM $(n=6)$

\begin{tabular}{|c|c|c|c|c|c|}
\hline Element & SRM value & $\operatorname{UAE}(\bar{x} \pm t s / \sqrt{n})$ & $\mathrm{CAD}(\bar{x} \pm t s / \sqrt{n})$ & \% Recovery (UAE/CAD) & $t_{\text {experimental }}$ \\
\hline \multicolumn{6}{|c|}{ Microelements $\left(\mu \mathrm{g} \mathrm{g}^{-1}\right)$} \\
\hline $\mathrm{Mn}$ & $54.1 \pm 1.1$ & $53.77 \pm 1.01$ & $53.77 \pm 1.34$ & $99.4 / 99.4$ & -0.226 \\
\hline $\mathrm{Fe}$ & $82.7 \pm 2.6$ & $82.8 \pm 0.64$ & $82.8 \pm 0.60$ & $100.1 / 100.1$ & -0.421 \\
\hline $\mathrm{Cu}$ & $5.69 \pm 0.13$ & $5.65 \pm 0.36$ & $5.79 \pm 0.32$ & $99.3 / 101.8$ & -1.505 \\
\hline $\mathrm{Zn}$ & $12.45 \pm 0.43$ & $12.05 \pm 0.58$ & $11.95 \pm 0.48$ & $96.8 / 96.0$ & 0.604 \\
\hline \multicolumn{6}{|c|}{ Macroelements ( $\mathrm{mg} \mathrm{g}^{-1}$ ) } \\
\hline $\mathrm{Mg}$ & $2.71 \pm 0.12$ & $2.67 \pm 0.23$ & $2.75 \pm 0.18$ & $98.5 / 98.5$ & -0.672 \\
\hline $\mathrm{K}$ & $16.08 \pm 0.21$ & $16.52 \pm 0.36$ & $16.63 \pm 0.24$ & $102.7 / 103.4$ & -0.798 \\
\hline $\mathrm{Ca}$ & $15.25 \pm 0.10$ & $15.34 \pm 0.38$ & $15.45 \pm 0.41$ & $100.6 / 101.3$ & -1.154 \\
\hline
\end{tabular}
$(\bar{x} \pm t s / \sqrt{n})=$ mean $\pm \mathrm{CI}(\mathrm{p}<0.05), \mathrm{CI}=$ Confidence interval

\subsubsection{Vortexing and sonication time influence on extraction recoveries}


The required quantity of SRM and each fruit peels powder along with extracting agent was added to vortexing tube separately and subject to pre-sonicated (vortexing) for different time intervals (5-15 min.). After the vortexing the tube was placed in ultrasonic bath, $5 \mathrm{~min}$. vortexing was noted as the optimum time for extracting both the micro and microelements from SRM and all samples (pomegranate, orange, lemon, mango, and grapefruit) understudy to achieve excellent recoveries. Increase in vortexing time (10 or $15 \mathrm{~min}$.) did not show any increment in recoveries (supplementary data, Table 9S-11S). UAE efficiency increased while increasing the sonication time (Fig. 1a) but the maximum recoveries of micro and microelements from SRM was obtained at 6 min. sonication time by using $\mathrm{HNO}_{3}-\mathrm{H}_{2} \mathrm{O}_{2}$ as extracting agents. It was observed that the sonication more than $6 \mathrm{~min}$. did not show any increase in recovery of micro and microelements from SRM. So the optimum recoveries were achieved by using dilute acid with hydrogen peroxide as extracting which offers practical advantages over CAD methods where a extended time is required to digest the sample ${ }^{34}$.

\subsubsection{Extracting agents influence on extraction recoveries}

The influence of extracting agents including $\mathrm{HNO}_{3}$ [EA-1], $\mathrm{HNO}_{3}-\mathrm{HCl}(1: 3)$ [EA-2], and $\mathrm{HNO}_{3}-\mathrm{H}_{2} \mathrm{O}_{2}$ (2:1) [EA3] were also studied over the extraction of micro and macroelements from SRM and fruit peels powder. A vortexing and sonication time was fixed at 5 and $6 \mathrm{~min}$. respectively at temperature of $60^{\circ} \mathrm{C}$ while using the extracting agents and higher recoveries were obtained by using EA-3, which is an acid-oxidant mixture (Fig. 1b). The extraction recoveries of micro and macroelements from SRM by using rest of two extracting (single acid, EA-1 and combination of two acids, EA-2) agents were comparative lower (supplementary data, Table 5S, 6S). Traditionally strong oxidizing acid $\left(\mathrm{HClO}_{4}\right)$ alone or in combination with other oxidant gave excellent extraction as compared to weak oxidizing acid $\left(\mathrm{HNO}_{3}\right)$ because organic matter present in plant material have an important role in releasing metals. So the combination of oxidizing acid $\left(\mathrm{HNO}_{3}\right)$ with oxidizing agent $\mathrm{H}_{2} \mathrm{O}_{2}$ dissociate hydroxyl $(\mathrm{OH}$.) radicals on heating that could attack organic matter, hence the efficiency of extraction increases ${ }^{22,34}$.

\subsubsection{Temperature influence on extraction recoveries}

Variation in temperature $\left(30,60,90^{\circ} \mathrm{C}\right)$ of ultrasonic bath was demonstrated for extraction of micro and macroelements in fruit peels powder to assess the effect of temperature on extraction performance. Increasing the temperature of extracting agents along with increment in sonication time resulted in formation of free radical which accelerate the reaction involved in the digestion of samples. Extraction recoveries were also assess by increasing time of vortexing along with varied condition of temperature $\left(30,60\right.$ and $\left.90^{\circ} \mathrm{C}\right)$. The data showed that (Fig. 2 and supplementary data, Table 9S-11S) the extraction recovery did not increase while increasing the vortexing time and temperature. To release the micro and macroelements from $\mathrm{SRM}, 60^{\circ} \mathrm{C}$ temperature was optimum so the temperature higher than $60^{\circ} \mathrm{C}$ was necessary for efficient extraction of metals from SRM and real samples under study as compared to extraction at lower or room temperature ${ }^{34,35}$.

\subsection{Validation of proposed method}


The errors in the analytical methods determine the accuracy of results on the basis of difference between the actual values and determined values of SRM which enable us to make the decision about the method adopted for analysis. The magnitude of sample matrix, purity of reference standard, environmental condition of laboratory as well as stability of instrument play a vital role to get accurate results, so to ensure accuracy during the analysis of micro and macroelements in real samples, SRM was analyzed and results are presented in terms of percentage recovery studies (Table 6) which are obtained in ranges between $96.8-102.7 \%$ and these best recovery values determine the excellent extraction efficiency of UAE method. A liner calibration curve $(y=m x+b)$ was obtained by plotting the nominal concentration $(x)$ of each element against the relevant peak height $(\mathrm{y})$ while selecting a dynamic range of $0.2-1.0 \mu \mathrm{g} / \mathrm{mL}$ for $\mathrm{Mg}, \mathrm{Mn}$, and $\mathrm{Zn}, 10-30 \mu \mathrm{g} / \mathrm{mL}$ for $\mathrm{Ca}, 1-5 \mu \mathrm{g} / \mathrm{mL}$ for $\mathrm{Fe}, \mathrm{Cu}$, and $\mathrm{K}$. Each analyte under investigation has a nominal concentration $x=0.2,0.4,0.6,0.8$ and $1.0 \mu \mathrm{g} / \mathrm{mL}$ for $\mathrm{Mg}, \mathrm{Mn}$ and $\mathrm{Zn}, \mathrm{x}=10,15,20,25$ and 30 $\mu \mathrm{g} / \mathrm{mL}$ for $\mathrm{Ca}, \mathrm{x}=1,2,3,4$ and $5 \mu \mathrm{g} / \mathrm{mL}$ for $\mathrm{Fe}, \mathrm{Cu}$ and $\mathrm{K}$. Where " $\mathrm{m}$ " and "b" represented the slope and intercept respectively. The necessary parameters of linear calibration curve are shown in Table 7.

Table 7

Parameters of the calibration curve, results of detection limits, and precision studies

\begin{tabular}{|lllllll|}
\hline Metal & $\mathbf{m}$ & $\mathbf{b}$ & $\mathbf{r}^{2}$ & LOD $\left(\mu \mathrm{g} \mathrm{g}^{-1}\right)$ & LOQ $\left(\mu \mathrm{g} \mathrm{g}^{-1}\right)$ & \% RSD \\
\hline $\mathrm{Mn}$ & 0.1338 & 0.1532 & 0.9987 & 0.012 & 0.040 & 1.41 \\
$\mathrm{Fe}$ & 0.0982 & 0.1384 & 0.9991 & 0.017 & 0.056 & 0.43 \\
$\mathrm{Cu}$ & 0.7552 & 0.1973 & 0.9989 & 0.019 & 0.063 & 1.38 \\
$\mathrm{Zn}$ & 0.1231 & 0.1452 & 0.9981 & 0.018 & 0.059 & 2.29 \\
$\mathrm{Mg}$ & 0.4293 & 0.2180 & 0.9998 & 0.006 & 0.017 & 1.67 \\
$\mathrm{~K}$ & 11.200 & 9.110 & 0.9978 & 0.058 & 0.175 & 0.59 \\
$\mathrm{Ca}$ & 0.3168 & 0.2314 & 0.9991 & 0.023 & 0.053 & 0.87 \\
\hline
\end{tabular}

The lower values of detection limits (LOD and LOQ) indicate that the method provided adequate sensitivity as shown in Table 7. The repeatability $(n=10)$ were performed to check the precision of method and results were presented in \% RSD which were obtained in ranged of 0.43 to 2.29 (Table 7) during the analysis of SRM which is good enough and in compliance with the FDA manual (\% RSD $<7)$.

\subsection{Analysis of fruit peels powder samples}

The optimized UAE procedure was applied to fruit peels for extraction of the micro ( $\mathrm{Mn}, \mathrm{Fe}, \mathrm{Cu}$, and $\mathrm{Zn}$ ) and macroelements $(\mathrm{Mg}, \mathrm{K}$, and $\mathrm{Ca}$ ) and subsequently, these were determined by FAAS, results are presented in Table 8.

Table 8. Contents of micro and macroelements in fruit peel samples using UAE method 


\begin{tabular}{llllllll}
\hline Fruit sample & \multicolumn{6}{l}{ Micro and macroelements concentration $(\mathrm{mg} / 100 \mathrm{~g}) \bar{x} \pm \mathrm{CI}$} \\
\cline { 2 - 8 } & $\mathrm{Mn}$ & $\mathrm{Fe}$ & $\mathrm{Cu}$ & $\mathrm{Zn}$ & $\mathrm{Mg}$ & $\mathrm{K}$ & $\mathrm{Ca}$ \\
\hline Pomegranate & $0.41 \pm 0.04$ & $1.36 \pm 0.05$ & $0.06 \pm 0.02$ & $0.85 \pm 0.12$ & $49.33 \pm 3.79$ & $728.00 \pm 3.79$ & $277.33 \pm 9.39$ \\
Orange & $0.22 \pm 0.06$ & $2.22 \pm 0.10$ & $0.13 \pm 0.04$ & $0.82 \pm 0.13$ & $48.67 \pm 5.16$ & $680.00 \pm 6.56$ & $471.33 \pm 13.65$ \\
Lemon & $0.47 \pm 0.09$ & $1.32 \pm 0.12$ & $0.12 \pm 0.04$ & $0.84 \pm 0.08$ & $74.00 \pm 4.96$ & $867.00 \pm 4.96$ & $795.66 \pm 18.28$ \\
Mango & $0.54 \pm 0.04$ & $6.50 \pm 0.16$ & $0.29 \pm 0.05$ & $1.03 \pm 0.15$ & $141.33 \pm 5.16$ & $1501.67 \pm 10.02$ & $454.00 \pm 9.92$ \\
Grapefruit & $0.36 \pm 0.06$ & $3.53 \pm 0.09$ & $0.14 \pm 0.04$ & $0.84 \pm 0.12$ & $79.33 \pm 3.78$ & $984.33 \pm 13.66$ & $801 \pm 17.88$ \\
\hline
\end{tabular}

$(\bar{x} \pm t s / \sqrt{n})=$ mean $\pm \mathrm{CI}(\mathrm{p}<0.05, \mathrm{n}=3), \mathrm{CI}=$ Confidence interval

The highest Mn content was found in mango peel ranged between $0.49-0.60 \mathrm{mg} / 100 \mathrm{~g}$ (Table $8 \mathrm{~S}$, supplementary data) which is about $4 \%$ of dietary reference intake (DRI, $8-13 \mathrm{mg} /$ day) ${ }^{36}$ while the lowest concentration was found in orange peel ranged between $0.19-0.22 \mathrm{mg} / 100 \mathrm{~g}$ ( $2 \%$ of DRI). The concentration of $\mathrm{Mn}$ reported by Czech et al. in the peels of orange $(0.13 \mathrm{mg} / 100 \mathrm{~g})$, lemon $(0.05 \mathrm{mg} / 100$ $\mathrm{g})$, and red grapefruit $(0.10 \mathrm{mg} / 100 \mathrm{~g})$ from Turkey ${ }^{20}$ is less than that the results are found in our study (Table 8), while $0.21-0.34 \mathrm{mg} / 100 \mathrm{~g} \mathrm{Mn}$ was found in orange cultivar (lima and pera orange) from Brazil 37 which is comparable with concentration found in our samples under investigations.

Our study showed that mango peel contained the highest Fe concentration $(6.5 \mathrm{mg} / 100 \mathrm{~g})$ that is $80.2 \%$ of the estimated average requirement (EAR, $5.0-8.1 \mathrm{mg} /$ day) and $36.1 \%$ of recommended dietary allowance (RDA, 8-18 mg/day), so both parameters cover the DRI as $5.0-18 \mathrm{mg} /$ day for both males and females. Grapefruit also contained an appreciable amount of Fe $(3.53 \mathrm{mg} / 100 \mathrm{~g})$ while lemon and pomegranate have almost the same concentration (Table 8). The concentration of Fe reported for the peels of orange $(0.51 \mathrm{mg} / 100 \mathrm{~g})$, lemon $(0.34 \mathrm{mg} / 100 \mathrm{~g})$ and red grapefruit $(0.23 \mathrm{mg} / 100 \mathrm{~g})$ from Turkey 20 is less than that of the results are found in our study (Table 8), while $1.01 \mathrm{mg} / 100 \mathrm{~g} \mathrm{Fe}$ was found in orange cultivar (lima orange) from Brazil ${ }^{37}$.

The Cu content in all the fruit peels was found in the range between $0.06-0.29 \mathrm{mg} / 100 \mathrm{~g}$ (Table $8 \mathrm{~S}$, supplementary data) while the highest concentration was found in mango peel ranged between $0.27-$ $0.31 \mathrm{mg} / 100 \mathrm{~g}$ which contribute $32.2 \%$ of DRI $(0.7-0.9 \mathrm{mg} /$ day) including EAR, $0.70 \mathrm{mg} /$ day and RDA, $0.90 \mathrm{mg} /$ day for both males and females with aged group ranged between 18-70 years. The Cu content was found in lima and pera orange was $0.06 \mathrm{mg} / 100 \mathrm{~g}$ and $0.09 \mathrm{mg} / 100 \mathrm{~g}$ originate to Brazil ${ }^{37}$ while the concentration of Cu reported for the peels of orange $(0.15 \mathrm{mg} / 100 \mathrm{~g})$, lemon $(0.04 \mathrm{mg} / 100 \mathrm{~g})$ and red grapefruit $(0.08 \mathrm{mg} / 100 \mathrm{~g})$ from Turkey ${ }^{20}$.

The $\mathrm{Zn}$ content in all the fruit peels was found in ranged between $0.78-1.10 \mathrm{mg} / 100 \mathrm{~g}$ (Table $8 \mathrm{~S}$, supplementary data) while the highest concentration was found in mango peel $(1.03 \mathrm{mg} / 100 \mathrm{~g})$ which contribute $9.4 \%$ of DRI (6.8-11.0 mg/day) including EAR, ranged $6.8-9.4 \mathrm{mg} /$ day and RDA, ranged 8-11 $\mathrm{mg} /$ day for both males and females with aged group ranged between 18-51 years. The Zn content was found in lima and pera orange was $0.35 \mathrm{mg} / 100 \mathrm{~g}$ and $0.21 \mathrm{mg} / 100 \mathrm{~g}$ respectively originate to Brazil ${ }^{37}$ while the concentration of $Z n$ reported for the peels of orange $(0.25 \mathrm{mg} / 100 \mathrm{~g})$, lemon $(0.28 \mathrm{mg} / 100 \mathrm{~g})$ and red grapefruit $(0.33 \mathrm{mg} / 100 \mathrm{~g})$ from Turkey ${ }^{20}$. 
The highest content of $\mathrm{Mg}$ was found in mango peel ranged between 133-141 mg/100 $\mathrm{g}$ while the least concentration was found in pomegranate $(45-51 \mathrm{mg} / 100 \mathrm{~g})$ and orange $(47-51 \mathrm{mg} / 100 \mathrm{~g})$ which are comparable (Table 8S, supplementary data). The DRI contribution by mango peel is $33.6 \%$ including EAR, ranged $265-350 \mathrm{mg} /$ day and RDA, ranged $320-420 \mathrm{mg} /$ day for both males and females with aged group ranged between 18-70 years. The Mg content was found in lima and pera orange was 23.8 $\mathrm{mg} / 100 \mathrm{~g}$ and $27.8 \mathrm{mg} / 100 \mathrm{~g}$ respectively originate to Brazil ${ }^{37}$ while the concentration of $\mathrm{Mg}$ reported for the peels of orange $(13.2 \mathrm{mg} / 100 \mathrm{~g})$, lemon $(11.5 \mathrm{mg} / 100 \mathrm{~g})$ and red grapefruit $(10.0 \mathrm{mg} / 100 \mathrm{~g})$ from Turkey ${ }^{20}$.

The present study indicated that the mango peel is rich in $\mathrm{K}(1501.67 \mathrm{mg} / 100 \mathrm{~g})$ content while the least amount was found in orange peel $(680 \mathrm{mg} / 100 \mathrm{~g})$. The $\mathrm{K}$ content was found in lima and pera orange was $258.7 \mathrm{mg} / 100 \mathrm{~g}$ and $266 \mathrm{mg} / 100 \mathrm{~g}$ respectively originate to Brazil ${ }^{37}$ while the concentration of $\mathrm{K}$ reported for the peels of orange $(154 \mathrm{mg} / 100 \mathrm{~g})$, lemon $(127 \mathrm{mg} / 100 \mathrm{~g})$ and red grapefruit $(132 \mathrm{mg} / 100$ g) from Turkey ${ }^{20}$. The DRI contribution of $\mathrm{K}$ by mango peel is $31.9 \%$ as Al (adequate intake, 4700 $\mathrm{mg} /$ day), for both the genders with aged group ranged between $18-70$ years.

Among all the fruit peels, the highest Ca content was found in grapefruit peel $(801 \mathrm{mg} / 100 \mathrm{~g})$ while the least concentration was found in pomegranate $(277.33 \mathrm{mg} / 100 \mathrm{~g})$. Liu et al. reported the highest $\mathrm{Ca}$ content $(40 \mathrm{mg} / 100 \mathrm{~g})$ in orange peel ${ }^{38}$. The DRI contribution of Ca by mango peel is $66.8 \%$ as $\mathrm{Al}$, $1000-1200 \mathrm{mg} /$ day, for both the genders with aged group ranged between 18-70 years. The Ca content was found in lima and pera orange was $145.2 \mathrm{mg} / 100 \mathrm{~g}$ and $165.4 \mathrm{mg} / 100 \mathrm{~g}$ respectively originate to Brazil ${ }^{37}$ while the concentration of Ca reported for the peels of orange $(41.9 \mathrm{mg} / 100 \mathrm{~g})$, lemon $(31.8$ $\mathrm{mg} / 100 \mathrm{~g})$ and red grapefruit $(36.0 \mathrm{mg} / 100 \mathrm{~g})$ from Turkey 20 .

In conclusion, mango peel comprised of the highest concentration of $\mathrm{Mn}, \mathrm{Fe}, \mathrm{Cu}, \mathrm{Zn}, \mathrm{Mg}$, and $\mathrm{K}$, while the Ca content was found less than orange, lemon and pomegranate peels. Special attention should be paid to such a nutritionally rich peel powder of mango for its potential use as a component of functional food. Different food cereals can be fortified with these fruit peel powders especially mango peel powder to meet the body's ongoing demand for individual minerals. Since mineralization (Fig. 3) is an important modifiable factor in the development and maintenance of bone mass and the prevention of osteoporosis. Concerning nutrition and health, this research showed that fruit peels of pomegranate, orange, lemon, mango, and grapefruit contain an appreciable amount of micro and macroelements that are good for bone health and could have osteo-protective effects.

\section{Conclusions}

In this study, an ultrasound-assisted extraction method was optimized by varying the parameters of extraction and using different extracting agents for the micro ( $\mathrm{Mn}, \mathrm{Fe}, \mathrm{Cu}$, and $\mathrm{Zn}$ ) and macroelements ( $\mathrm{Mg}, \mathrm{K}$, and $\mathrm{Ca}$ ) composition in the peels powder of some common fruits including pomegranate, orange, lemon, mango and grapefruit.The composition of mentioned elements was consequently determined by optimized and validated FAAS method. SRM was also analyzed by CAD method to check the 
performance and comparison of UAE to determine the significant difference between both methods. The significance difference at $95 \%$ confidence of interval $(p=0.05)$ was assessed by comparing the $t_{\text {critical }}$ (cut off point on the $t$ distribution) and $t_{\text {experimental }}$ (experimentally compare the means of two groups) for both the methods (CAD and UAE). The value of $t_{\text {critical }}(2.57)$ was more than $t_{\text {experimental }}$ at five degrees of freedom ( $\mathrm{n}-1=5)$ which indicates no significant difference in obtained values of $\mathrm{Mn}, \mathrm{Fe}, \mathrm{Cu}, \mathrm{Zn}, \mathrm{Mg}, \mathrm{K}$, and Ca present in SRM by using both the methods. Concerning nutrition and health, fruit peels powder is a very valuable source of micro and macroelements for the patients of osteoporosis in terms to overcome skeletal abnormalities and improve bone health. On the basis of literature, hypothesis was established for the management of osteoporosis by minerals, and fruit peels are rich source of minerals and is a

potential organic source of minerals rather to use their salts as source of minerals. This research is just to explain the role of mineralization for development and maintenance of bone mass and the prevention of osteoporosis and fruit peels are the rich source of minerals and suggest the utilization of their powder as multielement source along with other medication used to manage osteoporosis. The management of osteoporosis is not solely explained to utilize the fruit peel powder as remedy but their use along with other medication is recommended

\section{Declarations}

\section{Acknowledgement}

This research work was funded by Institutional Fund Projects under grant no (IFPIP: 1042-665-1442). Therefore, authors gratefully acknowledged technical and financial support from the Ministry of Education and King Abdulaziz University, Jeddah, Saudi Arabia

\section{References}

1. Dennison, E., Mohamed, M. A. \& Cooper, C. Epidemiology of osteoporosis. Rheum. Dis. Clin, 32, 617629 (2006).

2. Della Pepa, G. \& Brandi, M. L. Microelements for bone boost: the last but not the least. Clin. Cases Miner. Bone Metab, 13, 181-185 (2016).

3. Aaseth, J., Boivin, G. \& Andersen, O. Osteoporosis and trace elements-an overview. J. Trace Elem. Med. Biol, 26, 149-152 (2012).

4. Khan, A. H., Jafri, L., Ahmed, S. \& Noordin, S. Osteoporosis and its perspective in Pakistan: A review of evidence and issues for addressing fragility fractures. Annals of Medicine and Surgery, 29, 19-25 (2018).

5. Rodríguez, J. \& Mandalunis, P. M. A review of metal exposure and its effects on bone health. J. Toxicol. 2018, Pages 11 (2018).

6. Bonjour, J. P., Guéguen, L., Palacios, C., Shearer, M. J. \& Weaver, C. M. Minerals and vitamins in bone health: the potential value of dietary enhancement. Br. J. Nutr, 101, 1581-1596 (2009). 
7. Peters, B. S. E. \& Martini, L. A. Nutritional aspects of the prevention and treatment of osteoporosis. Arquivos Brasileiros de Endocrinologia \& Metabologia, 54, 179-185 (2010).

8. Weaver, C. et al. Calcium plus vitamin D supplementation and risk of fractures: an updated metaanalysis from the National Osteoporosis Foundation. Osteoporos. Int, 27, 367-376 (2016).

9. Aina, V. et al. Magnesium-and strontium-co-substituted hydroxyapatite: the effects of doped-ions on the structure and chemico-physical properties. J. Mater. Sci.: Mater. Med, 23, 2867-2879 (2012).

10. Tucker, K. L. et al. Potassium, magnesium, and fruit and vegetable intakes are associated with greater bone mineral density in elderly men and women. The American Journal of Clinical Nutrition, 69, 727-736 (1999).

11. Castiglioni, S., Cazzaniga, A., Albisetti, W. \& Maier, J. A. Magnesium and osteoporosis: current state of knowledge and future research directions. Nutrients, 5, 3022-3033 (2013).

12. Buclin, T. et al. Diet acids and alkalis influence calcium retention in bone. Osteoporos. Int, 12, 493499 (2001).

13. Liu, R. et al. Effects of manganese deficiency on the microstructure of proximal tibia and OPG/RANKL gene expression in chicks. Vet. Res. Commun, 39, 31-37 (2015).

14. Parelman, M., Stoecker, B., Baker, A. \& Medeiros, D. Iron restriction negatively affects bone in female rats and mineralization of hFOB osteoblast cells. Exp. Biol. Med, 231, 378-386 (2006).

15. Wright, I. et al. Bone remodelling is reduced by recovery from iron-deficiency anaemia in premenopausal women. J. Physiol. Biochem, 69, 889-896 (2013).

16. Kubiak, K., Klimczak, A., Dziki, Å., Modranka, R. \& Malinowska, K. Influence of copper (II) complex on the activity of selected oxidative enzymes. Polski Merkuriusz Lekarski: Organ Polskiego Towarzystwa Lekarskiego, 28, 22-25 (2010).

17. Yamaguchi, M. Role of nutritional zinc in the prevention of osteoporosis. Mol. Cell. Biochem, 338, 241-254 (2010).

18. Zofková, I., Nemcikova, P. \& Matucha, P. Trace elements and bone health. Clinical Chemistry and Laboratory Medicine (CCLM), 51, 1555-1561 (2013).

19. Morais, D. R. et al. Proximate composition, mineral contents and fatty acid composition of the different parts and dried peels of tropical fruits cultivated in Brazil. J. Braz. Chem. Soc, 28, 308-318 (2017).

20. Czech, A. et al. Mineral content of the pulp and peel of various Citrus fruit cultivars. Biol. Trace Elem. Res, 193, 555-563 (2020).

21. Manzoor, M., Anwar, F., Mahmood, Z., Rashid, U. \& Ashraf, M. Variation in minerals, phenolics and antioxidant activity of peel and pulp of different varieties of peach (Prunus persica L.) fruit from Pakistan., 17, 6491-6506 (2012).

22. Kazi, T. G. et al. Evaluation of an ultrasonic acid digestion procedure for total heavy metals determination in environmental and biological samples. J. Hazard. Mater, 161, 1391-1398 (2009). 
23. Khajeh, M. Optimization of microwave-assisted extraction procedure for zinc and copper determination in food samples by Box-Behnken design. J. Food Compos. Anal, 22, 343-346 (2009).

24. Güngör, H. \& Elik, A. Comparison of ultrasound-assisted leaching with conventional and acid bomb digestion for determination of metals in sediment samples. Microchem. J, 86, 65-70 (2007).

25. Krasnodębska-Ostręga, B., Kaczorowska, M. \& Golimowski, J. Ultrasound-assisted extraction for the evaluation of element mobility in bottom sediment collected at mining and smelting $\mathrm{Pb}-\mathrm{Zn}$ ores area in Poland. Microchim. Acta, 154, 39-43 (2006).

26. Costa, V. C. et al. Use of mixture design with minimal restrictions to optimize an extraction procedure employing diluted acids assisted by ultrasound and microwave for nutrient element determination in vegetal samples. J. Braz. Chem. Soc, 29, 1189-1198 (2018).

27. Padilha, C. C. F. et al. Evaluation of $\mathrm{Cu}, \mathrm{Mn}$, and $\mathrm{Se}$ in vegetables using ultrasonic extraction and GFAAS quantification. Food Anal. Methods, 4, 319-325 (2011).

28. Bendicho, C., Lavilla, I., Pena-Pereira, F. \& Romero, V. Green chemistry in analytical atomic spectrometry: a review. J. Anal. At. Spectrom, 27, 1831-1857 (2012).

29. Júnior, D. S., Krug, F. J., Pereira, M. G. \& Korn, M. Currents on ultrasound-assisted extraction for sample preparation and spectroscopic analytes determination. Appl. Spectrosc. Rev, 41, 305-321 (2006).

30. Ahmed, M., Khaleeq, A., Huma, R. \& Munir, S. Atomic absorption and inductively coupled plasmaoptical emission spectroscopic method for determination of micronutrients and toxic metals in Curcuma longa L. to characterize human health toxicity. Spectrosc. Lett, 50, 432-439 (2017).

31. Ahmed, M., Qadir, M. A. \& Hussain, M. Q. Qualification of atomic absorption spectrometer in prospective view of pharmaceutical analysis. Amer. J. Anal. Chem, 5, 674-680 (2014).

32. Costa, F. S. et al. Multivariate optimization of an ultrasound-assisted extraction procedure for the determination of $\mathrm{Cu}, \mathrm{Fe}, \mathrm{Mn}$, and $\mathrm{Zn}$ in plant samples by flame atomic absorption spectrometry. Anal. Methods, 12, 2509-2512 (2020).

33. Ahmed, M. et al. Optimization and validation procedure for elemental composition of fresh and pasteurized milk in Pakistan employing microwave digestion followed by ICP-OES: A contribution to risk assessment. Food Anal. Methods, 9, 2933-2942 (2016).

34. Ahmed, E., Sharif, A., Ahmed, M. \& Ahmad, W. Optimization of Ultrasound-Assisted Extraction of Essential and Non-essential/Toxic Trace Metals in Vegetables and Their Determination by FAAS and ICP-OES: an Evaluation of Human Health Risk.Food Anal. Methods,1-14(2021).

35. Mason, T. J. \& Mason, T. J. Sonochemistry Vol. 2 (Oxford University Press New York, 1999).

36. Meyers, L. D., Hellwig, J. P. \& Otten, J. J. Dietary reference intakes: the essential guide to nutrient requirements (National Academies Press, 2006).

37. de Barros, M., de Castro Ferreira, H. R., Genovese, M. \& T. A. P. \& I. Antioxidant capacity and mineral content of pulp and peel from commercial cultivars of citrus from Brazil. Food Chem, 134, 18921898 (2012). 
38. Liu, Y., Heying, E. \& Tanumihardjo, S. A. History, global distribution, and nutritional importance of citrus fruits. Comprehensive Reviews in Food Science and Food Safety, 11, 530-545 (2012).

\section{Figures}
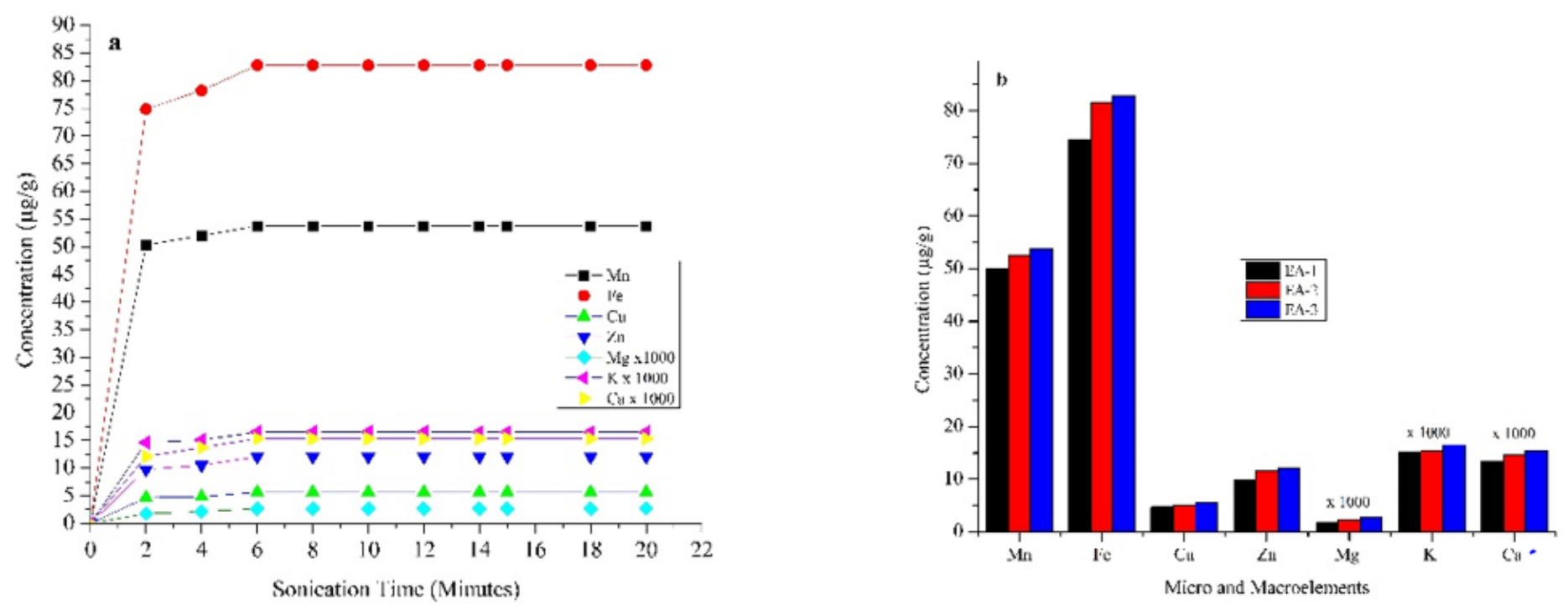

Figure 1

Sonication time (a) and extracting agents (b) influence on micro and macroelements recovery from SRM (NIST 1515) 


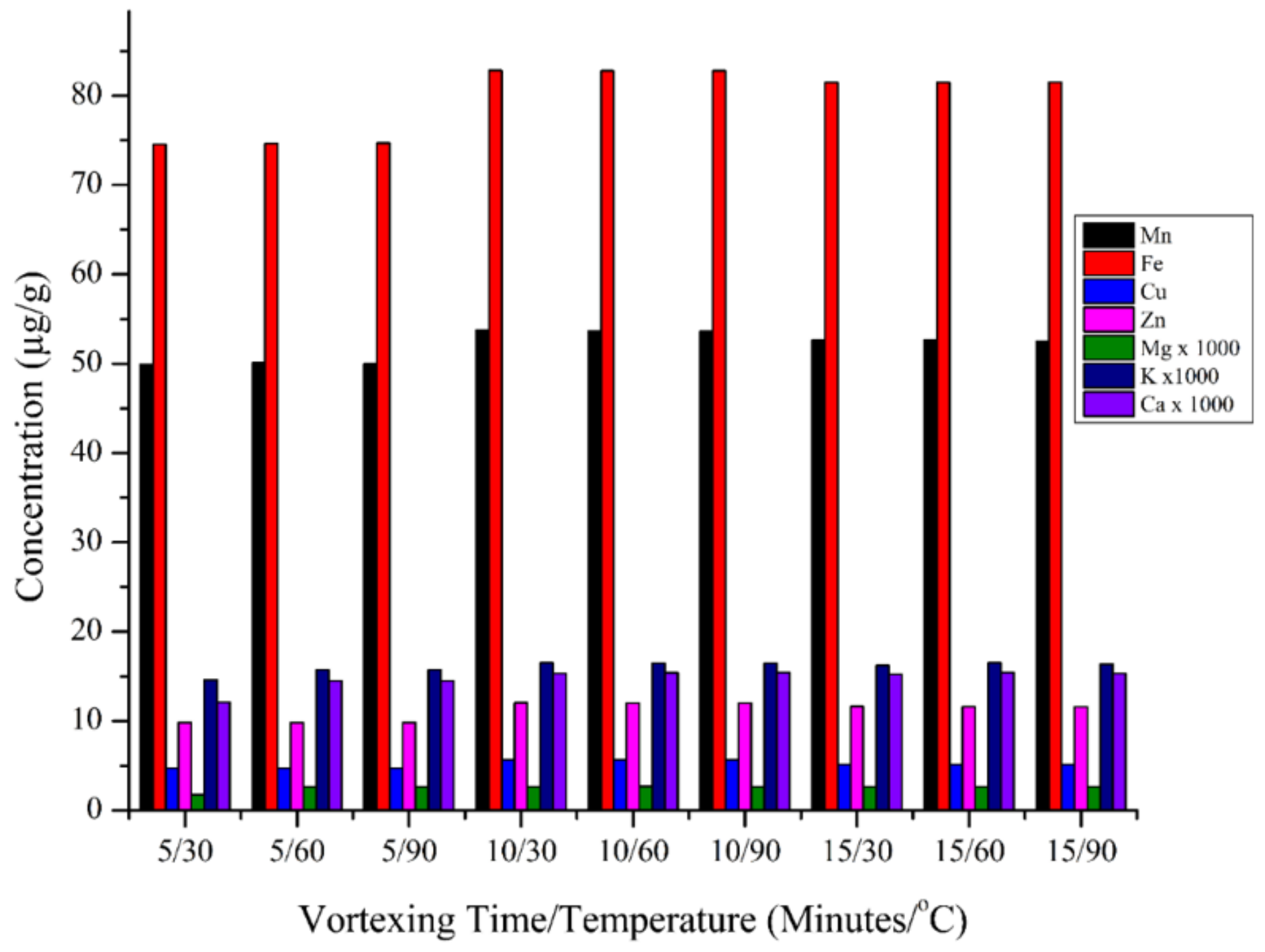

Figure 2

Vortexing time and temperature influence on micro and macroelements recovery from SRM 


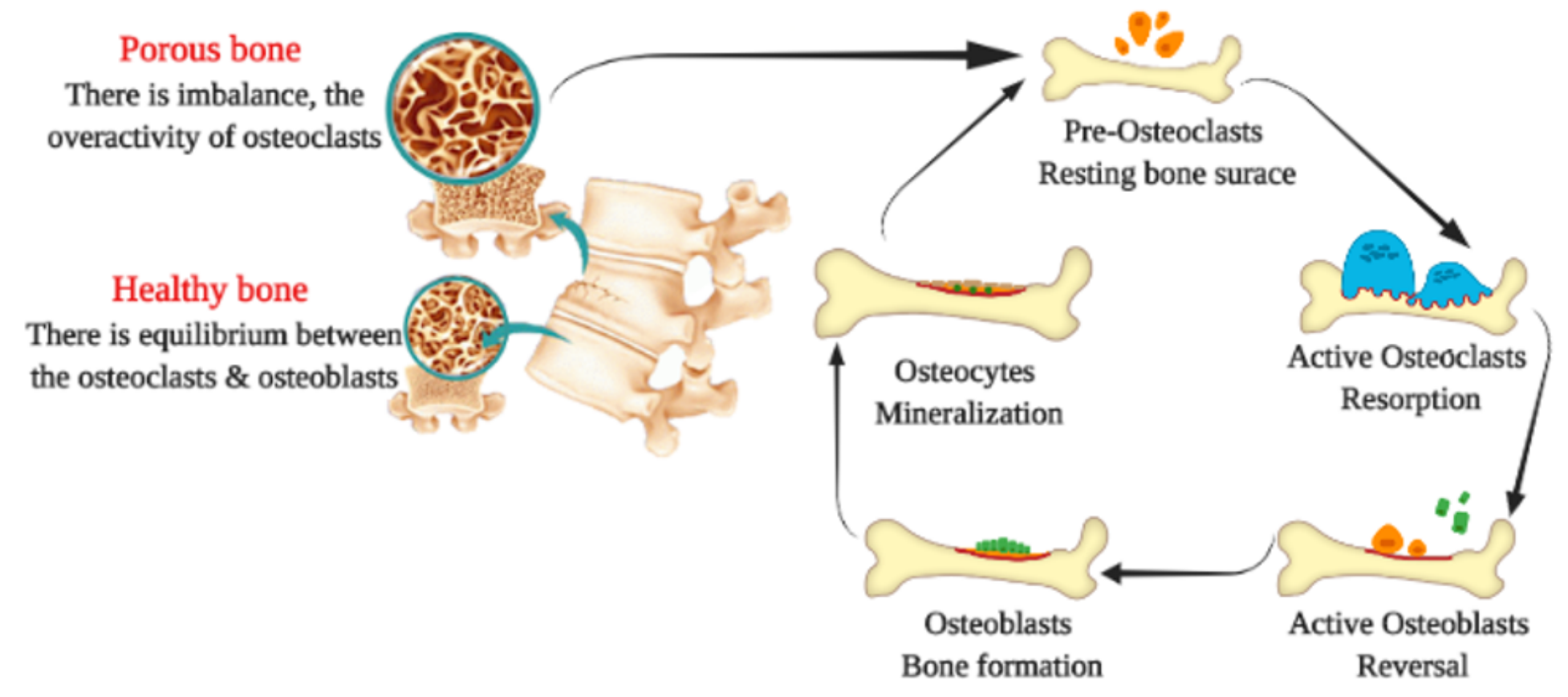

\section{Figure 3}

A proposed model for the potential osteo-protective effects of minerals

\section{Supplementary Files}

This is a list of supplementary files associated with this preprint. Click to download.

- SupplementarymaterialSciReports.docx 